\title{
The Shifting Structure of the Maltese Economy: Evidence from Chain-Linked Data
}

\author{
Jude Darmanin \\ Roberta Montebello \\ Warren Deguara \\ Economic Analysis Department, \\ Central Bank of Malta, \\ Castille Place Valletta, VLT 106o, Malta
}

DOI: https://doi.org/10.36941/mjss-2021-0031

Abstract

The economy of the Maltese islands has undergone significant structural change and diversification since the turn of the century. The aim of this study is to provide an overview of sectoral developments in output, employment, unit labour costs, and prices in Malta during the two decades to 2020. Analysis is conducted using the newly-available chain-linked sectoral national accounts data, which is a departure from previous studies. Furthermore, we complement our findings with a comparative analysis of structural developments in Malta and in the euro area. The results show that the Maltese economy underwent a significant shift towards the services sector between 2000 and 2020 . Sectors such as finance $\mathcal{E}$ insurance, information $\mathcal{E}$ communication, professional, scientific $\mathcal{E}$ technical activities, administrative $\mathcal{E}$ support services, and arts, entertainment $\mathcal{E}$ recreational services saw large increases in their shares of both output and employment. On the other hand, more traditional sectors such as manufacturing, construction, and food $\mathcal{E}$ accommodation services saw a decline in their relative importance. An analysis of productivity and cost developments also suggests that services sectors were generally the most productive during the period under study, while recording the highest levels of compensation per employee and the lowest unit labour costs. Nonetheless, sectoral productivity levels in Malta generally remain below those observed in the euro area. Output prices rose significantly in Malta between 2000 and 2020, generally reflecting the higher pace of economic growth when compared with the euro area.

Keywords: Sectoral economic composition; structural change; services; labour productivity; unit labour costs; price deflators; Malta; euro area

\section{Introduction}

As a small and open island economy, Malta has experienced significant economic and structural change during the first two decades of the twenty-first century, particularly after accession into the European Union (EU) in 2004 (Grech \& Zerafa, 2015). From an economy predominantly dependent on tourism and a large manufacturing sector, the country has witnessed a significant shift towards an increasingly diversified based on services economy and a higher-value manufacturing industry. In an earlier study on the structural change occurring within the Maltese economy, Grech (2015a) highlighted the expansion of the services sector in terms of both output and employment. As of 2014, the gross value added (GVA) of the agriculture and industrial sectors had halved compared to the 1980 , whereas the share of trade and services had increased to over $80 \%$ in nominal terms. These 
changes in turn led to the increased diversification of the Maltese economy (Cassar, 2017). The labour market has also undergone significant change, driven by a large inflow of foreigners and older workers into the employment pool, as well as through increasing female participation rates.

This study analyses the changing structure of the Maltese economy over the 2000-2020 period. Apart from EU accession, the analysed period also covers Malta's adoption of the euro in 2008, the global financial crisis and subsequent euro area sovereign debt crisis, the boom years of 2014 to 2019, and the downturn in 2020 following the onset of the COVID-19 pandemic. This review builds on the earlier findings by Grech (2015a), while incorporating more recent developments from 2015 onward. Furthermore, an updated review of the Maltese economic structure is necessary following a number of benchmark revisions to national accounts data that have taken place in recent years (NSO, 2020). This is especially relevant given that such revisions are likely to have altered previous conclusions.

This paper is the first to analyse structural developments in Malta using real data, following the publication of sectoral chain-linked national accounts data in mid-2020 by the National Statistics Office (NSO). It is also the first to provide an overview of developments in Malta's sectoral output deflators. The use of chain-linked data allows for a more accurate overview of sectoral structure and developments, as it enables a distinction to be made between developments in output volumes and in prices. This distinction is not possible when using nominal data, meaning that output shares could be distorted by changes in relative output prices across sectors.

Malta's accession into the EU brought about considerable change to the structure of the economy, particularly due to the liberalisation of markets and the removal of state aid and subsidies to traditionally protected sectors, such as manufacturing and air transport (Grech, 2015b). EU membership also facilitated the development of new, higher value services sectors such as financial services, maritime and logistics, information and technology, and gaming. These were further encouraged by targeted government policies and the upskilling of the labour force. The shift to services in Malta during the analysed period was by far the largest observed in the EU (Eurostat, 2021), leading to an increased average sectoral share of 12.3 percentage points of output and 14.0 percentage points of employment in 2014-2020, compared with the 2000-2006 subperiod.

At the same time, the composition of the manufacturing sector shifted from labour-intensive industries such as textiles to higher value sectors such as pharmaceuticals (Borg Caruana, 2018). Further structural change was brought about by the introduction of low-cost airlines in the late200os (Attard, 2020), the restructuring of the energy sector (Rapa, 2017), and numerous labour market reforms (Micallef, 2017). The latter were mainly focussed on increasing the participation of female and older workers, as well as facilitating the inflow of foreign workers (Grech, 2017) into the domestic labour force. In turn, these labour market reforms helped address the labour and skill shortages brought about by the rapid development of new industries (Micallef, 2019).

The first section of this paper looks at developments in the Maltese economic structure in terms of sectoral output shares and growth. Subsequently, we look at the evolution of the labour market and the impact of inward migration. This is followed by an overview of developments in productivity, compensation per employee, and unit labour costs (ULC), as well as an analysis of sectoral output deflators. The study is based on the sample period 2000-2020, divided into seven-year subperiods (2000-2006; 2007-2013; 2014-2020) for ease of analysis. Comparative figures are also provided for the euro area, in order to assess how the unique features of the Maltese economy have led to a divergence in economic structure when compared with that of the continent. Our concluding remarks and scope for further research are discussed in the final section.

\section{The Changing Structure of the Maltese Economy}

This section discusses how the structure of the Maltese economy has changed between 2000 and 2020. For this purpose, we calculated sectoral output shares using national accounts data measured in chain-linked volumes. The figures for Malta are shown in Table 1, with shares for the euro area also provided for comparison purposes. 
Table 1: Sectoral Output Shares In Malta And The Euro Area

subperiod averages

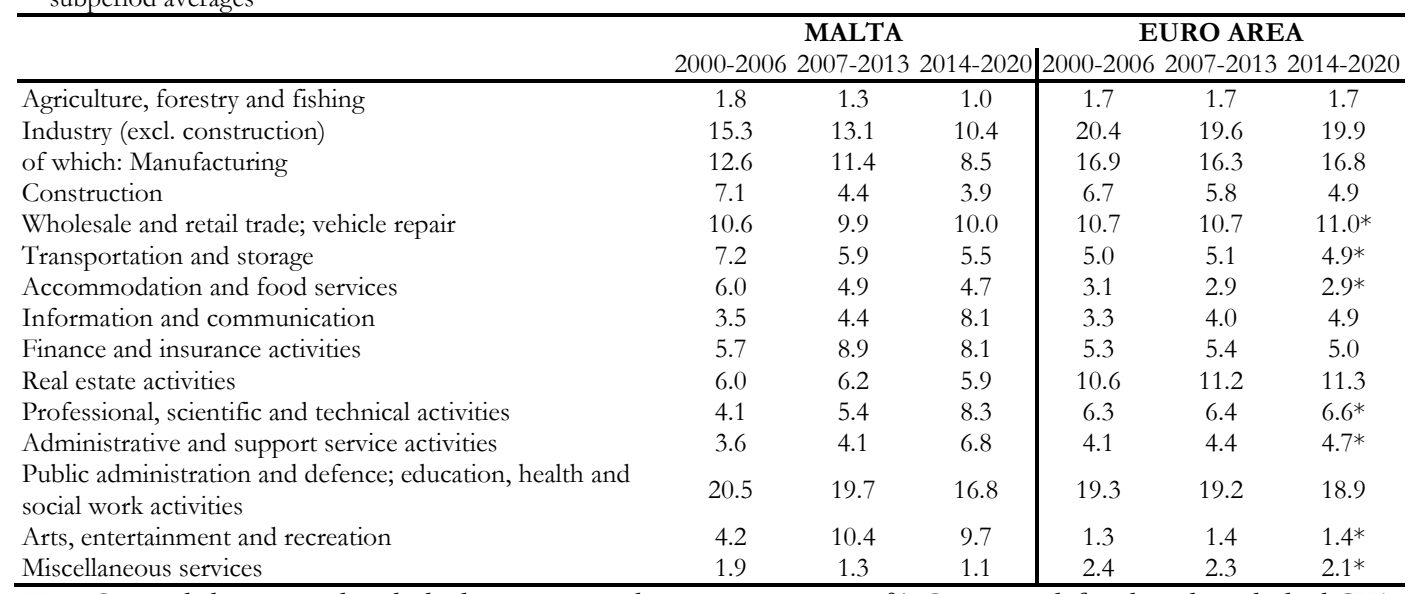

Note: Sectoral shares are chainlinked estimates and may not sum to 100\%. Output is defined as chain-linked GVA. Figures marked with * are averages for 2014-2019, as 2020 data was unavailable at the time of publication

Source: Eurostat; authors' calculations

As concluded by Grech (2015a), the share of industrial activities has declined since 200o. In particular, the share of the manufacturing sector, which averaged a share of $12.6 \%$ in $2000-2006$, dropped to $8.5 \%$ in 2014-2020. This reflects the downscaling of the manufacturing sector in Malta that occurred around the time of EU accession, partly reflecting increased external competition and the removal of trade protection (Grech 2015b; Borg Caruana 2018). The share of the construction sector also dropped markedly, from $7.1 \%$ to $3.9 \%$, while the relative importance of primary industries, such as agriculture \& fishing, in overall output remained small throughout the period under review. The large output share of the construction industry in 2000-2006 reflected the booming residential property market during the period around EU accession (Gatt \& Grech, 2016) as well as the large-scale public infrastructural projects ongoing at the time, such as the new state hospital and an upgrading of the road network under the Fifth Italian Protocol (Central Bank of Malta, 2003).

Conversely, industrial activities - especially manufacturing - remained an integral part of the euro area economy, accounting for $20 \%$ of GVA on average between 2014 and 2020 . This was roughly double the comparable figure in Malta. Indeed, the manufacturing sector largely retained its share in the euro area economy throughout the two decades since 2000 .

The decline in the share of industrial activities in Malta was mirrored in a significant increase in the share of services. Indeed, the total share of (predominantly) private services sectors rose from an average of 42.2\% in 2000-2006 to $58.1 \%$ in 2014-2020. This is higher than the share of services in euro area output, which averaged at $43.8 \%$ in the last subperiod and increased by only 2.4 percentage points when compared with the first subperiod. Indeed, output shares for all services sectors were higher in Malta than in the euro area during the last subperiod, except for real estate activities and miscellaneous services. ${ }^{2}$ This confirms the conclusion reached in Grech (2015a), which found that the increase in the share of services in Malta was the largest

\footnotetext{
${ }^{1}$ The aggregate for private services sectors excludes agriculture $\mathcal{E}$ fishing, industry, construction, and the sector comprising public administration, health E education.

${ }^{2}$ Miscellaneous services comprise NACE sectors $S, T$, and U. Sector $S$ includes other services activities, such as activities of non-profit organisations and trade unions, repair of consumer goods and equipment, and personal services. Sector T consists of activities of households as employers of domestic personnel and undifferentiated goodsand services-producing activities of private households for own use. Sector $U$ relates to the activities of extraterritorial organisations and bodies.
} 
increase experienced across the EU between 2004 and 2014.

This increase in the overall share of the services sector masks significant heterogeneity across sectors. The share of sectors such as information \& communication, professional, scientific \& technical activities, administrative \& support services, and arts, entertainment \& recreational services (which mainly comprises the gambling \& betting industry) rose sharply during the two decades since 200o. On the other hand, the average share of accommodation \& food services stood at $4.7 \%$ in $2014-$ 2020 , down from $6.0 \%$ in $2000-2006 .^{3}$ Similarly, the share of the sector comprising public administration, health, \& education declined, averaging $16.8 \%$ in $2014-2020$ from $20.5 \%$ in $2000-2006$. Indeed, the share of this predominantly public services sector stood below the euro area average of $18.9 \%$ in the last subperiod. At the same time, the wholesale \& retail trade sector maintained a relatively stable share of around $10.0 \%$ in the last two subperiods, which is only moderately lower than the $10.6 \%$ recorded in the first seven years.

The Maltese economy grew rapidly during the assessed period, particularly in the second half of the sample. Average output growth stood at $1.7 \%$ between 2001 and 2006 , before accelerating to $3.6 \%$ in 2007-2013 and 5.3\% in 2014-2020. This acceleration was mainly driven by the services sectors, as shown in Table 2.

Table 2: Chain-linked contirbutions to output growth

percentage points; subperiod averages

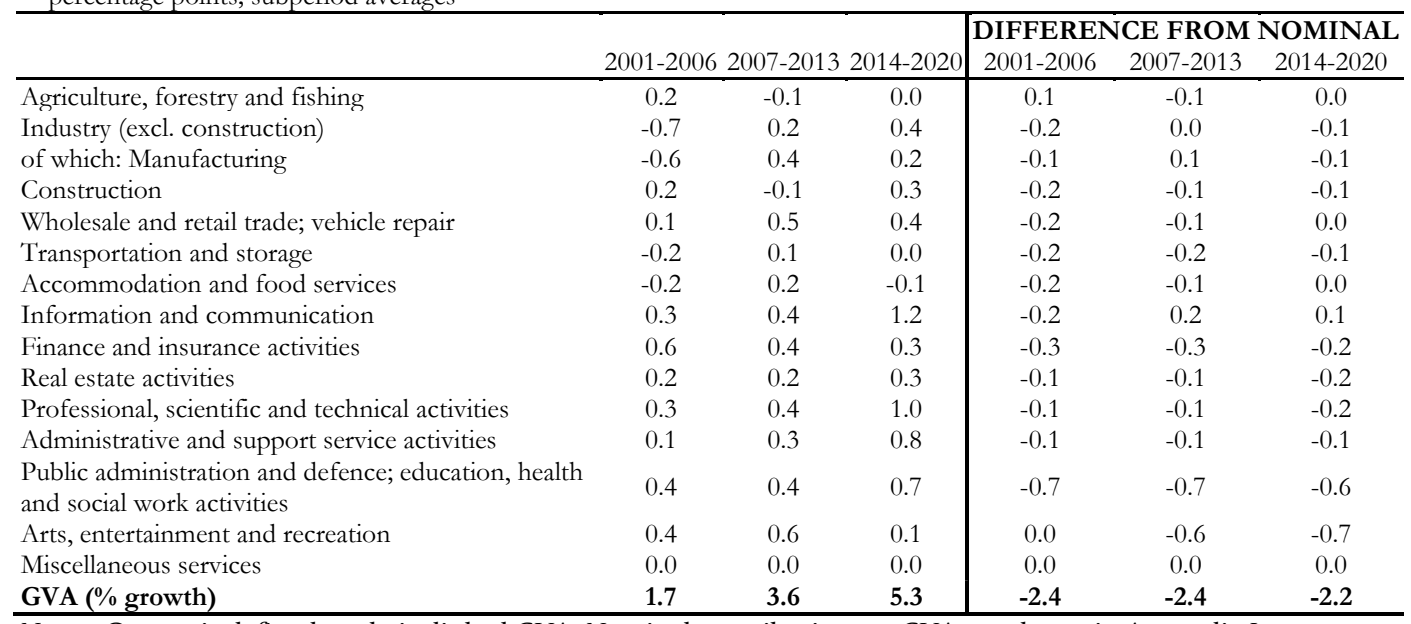

Notes: Output is defined as chain-linked GVA. Nominal contributions to GVA are shown in Appendix I

Source: Eurostat; authors' calculations

The economic expansion during the 2001-2006 subperiod was largely dominated by the newlyestablished services industries, such as finance \& insurance activities and arts, entertainment \& recreational services. On the other hand, the manufacturing sector, which was going through a period of downscaling, acted as the main drag on economic growth during the period. The sectors comprising transportation \& storage and accommodation \& food services also lowered output.

Growth in real output accelerated in the 2007-2013 subperiod, supported mainly by services sectors. In particular, the arts, entertainment \& recreation sector recorded a strong positive contribution, reflecting the development of the gambling \& betting industry in Malta. The wholesale

\footnotetext{
${ }^{3}$ The decline in the output share of food $\mathcal{E}$ accommodation does not necessarily reflect a decline in the share of tourism in the economy given that parts of tourist expenditure are reflected in other NACE categories (such as travel agents, transportation, entertainment, and cultural services).
} 
\& retail trade sector also contributed significantly to growth, reflecting a shift in consumption patterns and rising household incomes (Borg Caruana, 2019). The manufacturing sector registered positive growth on average during this seven-year period, which reflects the significant restructuring within the sector in favour of more high-value added industries such as pharmaceuticals and aircraft maintenance (Borg Caruana, 2018). On the other hand, the construction sector contributed negatively to growth, reflecting a period of slowdown in the property market (Gatt \& Grech, 2016) and the conclusion of major public sector projects.

GVA growth picked up further in the 2014-2020 period. During this period, growth was primarily driven by the information \& communication sector, the sector comprising professional, scientific \& technical activities, and the sectors comprising administrative \& support services and public administration, health \& education. Other services sectors, such as the finance \& insurance activities sector, also contributed positively, but to a lesser extent. Meanwhile, the manufacturing sector registered a positive contribution to growth during this period, suggesting that despite its decreased share in output, the sector remained an important driver of output growth. On the other hand, the accommodation \& food services sector registered a slightly negative contribution to growth. The latter sector was heavily impacted by the COVID-19 shock in 2020; indeed, between 2014 and 2019, food \& accommodation services registered a positive contribution of 0.4 percentage points, reflecting the rapid growth in the tourism industry during these years.

Table 2 highlights the benefits of using chain-linked output data when analysing Malta's economic structure, as opposed to the nominal data used in earlier studies (Grech, 2015a; Grech 2015b; Cassar, 2017). Overall output growth averaged 4.1\% in 2001-2006, 6.0\% in 2007-2013, and 7.6\% in 2014-2020 in nominal terms. ${ }^{4}$ This is higher than the growth indicated by chain-linked data, by 2.4 , 2.4, and 2.2 percentage points, respectively. This residual results from growth in output prices during the sample period, as explained further in the section on sectoral deflators below. In terms of sectoral contributions, chain-linked data mainly implies lower contributions for the public administration, health \& education sector, the arts, entertainment \& recreation sector, and the financial \& insurance activities sector, indicating that a significant part of the nominal increase in output registered in these sectors was driven by an increase in output prices.

\section{Sectoral Developments in Employment}

This section provides a snapshot of the structure of the Maltese labour market using national accounts employment data, as well as an analysis of how sectoral shares in total employment have changed since 2000 compared with the euro area.

The public administration \& defence, education, health \& social work sectors collectively employed around $24 \%$ of total workers throughout the time period under consideration. This is similar to the share recorded in the euro area. Following these predominantly public services sectors, the wholesale \& retail trade sector ranked second in terms of employment in Malta in the last subperiod. Although this sector's share in employment has decreased over time, it nonetheless overtook the manufacturing sector in the 2014-2020 period. On the other hand, employment levels in administrative \& support services activities have risen rapidly since 2000, with this sector becoming the fourth most important in terms of employment in the last subperiod. ${ }^{5}$

\footnotetext{
${ }^{4}$ Sectoral contributions to GVA in nominal terms are shown in Appendix I.

${ }^{5}$ Strong employment growth in the administrative and support service activities sector was driven by growth in the subsectors relating to employment activities, security $\mathcal{E}$ investigation activities, and services to buildings and landscapes. This may reflect increased outsourcing of such activities from other sectors (Micallef, 2016).
} 
Table 3: Shares of total employment

\begin{tabular}{|c|c|c|c|c|c|c|}
\hline & 2000-2006 & $\begin{array}{c}\text { MALTA } \\
2007-2013\end{array}$ & $2014-2020$ & $\begin{array}{r}\mathbf{E} \\
2000-2006\end{array}$ & $\begin{array}{l}\text { EURO ARE } \\
2007-2013\end{array}$ & $2014-2020$ \\
\hline Agriculture, forestry and fishing & 1.5 & 1.5 & 1.1 & 4.3 & 3.5 & 3.2 \\
\hline Industry (excl. construction) & 22.3 & 18.2 & 11.5 & 17.8 & 16.4 & 14.7 \\
\hline of which: Manufacturing & 19.3 & 15.8 & 10.5 & 16.4 & 15.1 & 13.4 \\
\hline Construction & 6.9 & 7.4 & 5.9 & 7.4 & 7.5 & 6.0 \\
\hline Wholesale and retail trade; vehicle repair & 16.0 & 15.3 & 14.2 & 15.1 & 15.0 & $14.6^{*}$ \\
\hline Transportation and storage & 5.7 & 5.6 & 5.6 & 5.0 & 4.9 & $4.9^{*}$ \\
\hline Accommodation and food services & 6.6 & 6.7 & 6.4 & 4.4 & 4.7 & $5.4^{*}$ \\
\hline Information and communication & 2.6 & 2.8 & 3.8 & 2.6 & 2.6 & 2.8 \\
\hline Finance and insurance activities & 4.0 & 5.4 & 5.3 & 2.8 & 2.7 & 2.5 \\
\hline Real estate activities & 0.3 & 0.4 & 0.9 & 1.0 & 1.0 & 1.0 \\
\hline Professional, scientific and technical activities & 3.0 & 3.8 & 6.2 & 5.3 & 5.7 & $6.5^{*}$ \\
\hline Administrative and support service activities & 3.7 & 4.8 & 8.5 & 5.3 & 5.9 & $7.1 *$ \\
\hline $\begin{array}{l}\text { Public administration and defence; education, health } \\
\text { and social work activities }\end{array}$ & 24.0 & 24.6 & 24.3 & 22.9 & 23.6 & 24.3 \\
\hline Arts, entertainment and recreation & 1.2 & 1.7 & 3.5 & 1.4 & 1.5 & $1.7^{*}$ \\
\hline Miscellaneous services & 2.2 & 2.4 & 2.7 & 4.9 & 5.1 & $5.2^{*}$ \\
\hline
\end{tabular}

\section{Source: Eurostat; authors' calculations}

The sectors which lost importance in terms of output generally also recorded a decreasing share in employment over time. Indeed, the employment share of non-services sectors such as manufacturing, construction, and primary industries declined between 2000 and 2020. In particular, the share of employment in manufacturing fell from an average $19.3 \%$ in the $2000-2006$ subperiod, to $10.5 \%$ in the 2014-2020 subperiod, mirroring developments in the sector's share in output. Despite the decline in the share of total employment, absolute levels of employment in the manufacturing sector rose slightly in the last subperiod, as the sector restructured and diversified. The manufacturing sector therefore remained one of the largest employers in Malta. Micallef (2016) called for caution in the interpretation of the decline in the share of certain sectors, such as manufacturing, since a proportion of this drop could be the result of outsourcing of certain activities.

Services sectors such as administrative \& support services, professional, scientific \& technical activities, and arts, entertainment \& recreation saw their shares in total employment double, when comparing the most recent subperiod with the 2000-2006 subperiod. The information \& communication sector, financial \& insurance activities and, to a lesser extent, real estate activities also registered an increased share of total employment during the period. Thus, the increasing share in output of services sectors is also mirrored in higher shares in total employment. Meanwhile, the employment share of the transportation \& storage sector and of the accommodation \& food service sector remained relatively stable over the years. In total, employment within predominantly private sector services industries increased by over 78,000 heads between 2000 and 2020 , compared with a drop of just below 4,ooo heads in industrial sectors.

This shift towards services sectors in Malta was stronger than that observed in the euro area during the corresponding period, once again mirroring developments in output shares. The total share of predominantly private services sectors in euro area employment rose from an average of $32.6 \%$ in $2000-2006$ to $37.1 \%$ in recent years, whereas in Malta there was a corresponding increase in the employment share of these sectors of 13.7 percentage points, to $43.0 \%$.

Table 4 confirms that within the private sector, employment growth was driven by sectors such as administrative \& support service activities, professional, scientific \& technical activities, the arts, entertainment \& recreation sector, and accommodation \& food services. The wholesale \& retail trade sector also had a sizeable contribution to employment growth in recent years. On the other hand, the manufacturing sector contributed negatively to employment growth on average in the first two 
subperiods and had only a marginal impact between 2014 and 2020. The sector comprising public administration, education \& health also contributed positively, driven by increased employment within health \& social work activities and, to a lesser extent, in education.

Table 4: Contributions to employment growth

percentage points; averages

\begin{tabular}{|c|c|c|c|}
\hline & $2001-2006$ & $2007-2013$ & $2014-2020$ \\
\hline Agriculture, forestry and fishing & 0.0 & 0.0 & 0.0 \\
\hline Industry (excl. construction) & -0.8 & -0.4 & 0.0 \\
\hline of which: Manufacturing & -0.7 & -0.3 & 0.1 \\
\hline Construction & 0.2 & 0.0 & 0.3 \\
\hline Wholesale and retail trade; vehicle repair & 0.3 & 0.2 & 0.5 \\
\hline Transportation and storage & 0.0 & 0.1 & 0.3 \\
\hline Accommodation and food services & 0.0 & 0.1 & 0.4 \\
\hline Information and communication & 0.0 & 0.2 & 0.2 \\
\hline Finance and insurance activities & 0.1 & 0.3 & 0.2 \\
\hline Real estate activities & 0.0 & 0.1 & 0.1 \\
\hline Professional, scientific and technical activities & 0.2 & 0.3 & 0.6 \\
\hline Administrative and support service activities & 0.2 & 0.3 & 1.1 \\
\hline Public administration and defence; education, health and social work activities & 0.3 & 0.7 & 0.9 \\
\hline Arts, entertainment and recreation & 0.1 & 0.2 & 0.4 \\
\hline Miscellaneous services & 0.1 & 0.1 & 0.1 \\
\hline Total employment (\% growth) & 0.8 & 2.3 & 5.5 \\
\hline
\end{tabular}

Source: Eurostat; authors' calculations

The substantial employment growth registered in recent years was facilitated by an increase in the participation rate of Maltese nationals and inward migration (Grech, 2017; Micallef, 2017). Although the unemployment rate decreased to around 4\% since 2017 (from $6.1 \%$ in 2013), reliance on foreign workers has increased. Their share in total employment increased substantially from an average of $6.4 \%$ in 2008-2013 to 20.1\% in 2014-2020 (see Table 5). ${ }^{6}$ Each economic sector recorded a higher share of foreign workers in total employment in the last subperiod, albeit to varying degrees. Apart from the construction sector, services sectors registered the largest increases in the share of foreign workers, namely the accommodation \& food services sector, the arts, entertainment \& recreation sector, professional, scientific \& technical activities, the information \& communication sector and, to a lesser extent, the sector relating to administrative \& support service activities. This large inflow of expatriates helped address the labour and skill shortages brought about by the rapid development of new industries (Micallef, 2019).

Table 5: Foreign workers in Malta

Share in total sectoral employment; averages

\begin{tabular}{lcc:c}
\hline & $2008-2013$ & $2014-2020^{1}$ & Change \\
\hline Agriculture, forestry and fishing & 2.3 & 8.4 & 6.1 \\
Industry (excl. construction) & 4.0 & 14.0 & 10.0 \\
of which: Manufacturing & 4.4 & 14.4 & 9.9 \\
Construction & 7.7 & 27.6 & 20.0 \\
Wholesale and retail trade; vehicle repair & 2.8 & 12.0 & 9.3 \\
Transportation and storage & 2.9 & 14.2 & 11.3 \\
Accommodation and food services & 13.9 & 37.5 & 23.6 \\
Information and communication & 7.9 & 25.9 & 18.0 \\
Finance and insurance activities & 5.0 & 16.4 & 11.4 \\
Real estate activities & 4.8 & 15.3 & 10.5 \\
Professional, scientific and technical activities & 11.2 & 31.1 & 19.9 \\
Administrative and support service activities & 17.4 & 34.4 & 17.0 \\
\hline
\end{tabular}

${ }^{6}$ An increase of 3.8 percentage points was recorded in the share of foreign workers in total employment between 2002-2007 and 2008-2013, substantially below the 13.7 percentage point increase registered in 2014-2020. 
Share in total sectoral employment; averages

\begin{tabular}{lcc:c}
\hline & $2008-2013$ & $2014-2020^{1}$ & Change \\
\hline Public administration and defence; education, health and social work activities & 2.4 & 7.2 & 4.8 \\
Arts, entertainment and recreation & 38.0 & 60.3 & 22.3 \\
Miscellaneous services & 8.1 & 23.5 & 15.4 \\
Total economy & $\mathbf{6 . 4}$ & $\mathbf{2 0 . 1}$ & $\mathbf{1 3 . 7}$ \\
\hline
\end{tabular}

Notes: Data for 2020 shown as at October 2020

Source: Eurostat; authors' calculations

\section{Sectoral Developments in Productivity Levels and Costs}

This section looks at sectoral trends in real productivity, employee compensation, and ULC in Malta during the two decades since 2000 .

Chart 1 shows average sectoral productivity levels, measured as the ratio of chain-linked output to the number of employed persons, in Malta and in the euro area for the 2000-2006 and 2014-2020 subperiods. In 2014-2020, the highest average levels of productivity in Malta were generated by services sectors. The arts, entertainment \& recreation sector recorded a productivity level of $€ 129,378$ per person employed, significantly higher than in most other sectors. Other service sectors, such as information \& communication, financial \& insurance activities, and professional, scientific \& technical activities also recorded productivity levels above the economy-wide average of €44,004 per head. Similarly, the most productive sectors in the euro area were services sectors, particularly finance \& insurance activities and the information \& communication sector.

Productivity within two of the sectors which have persistently accounted for large shares of employment over the past two decades in Malta - the public administration, health \& education sector and the wholesale \& retail trade sector - stood at the lower-end of the productivity spectrum during the subperiod under review. In particular, the public administration, health \& education sector recorded the third lowest average productivity level of €30,423 per person employed, followed only by the construction sector and miscellaneous services.

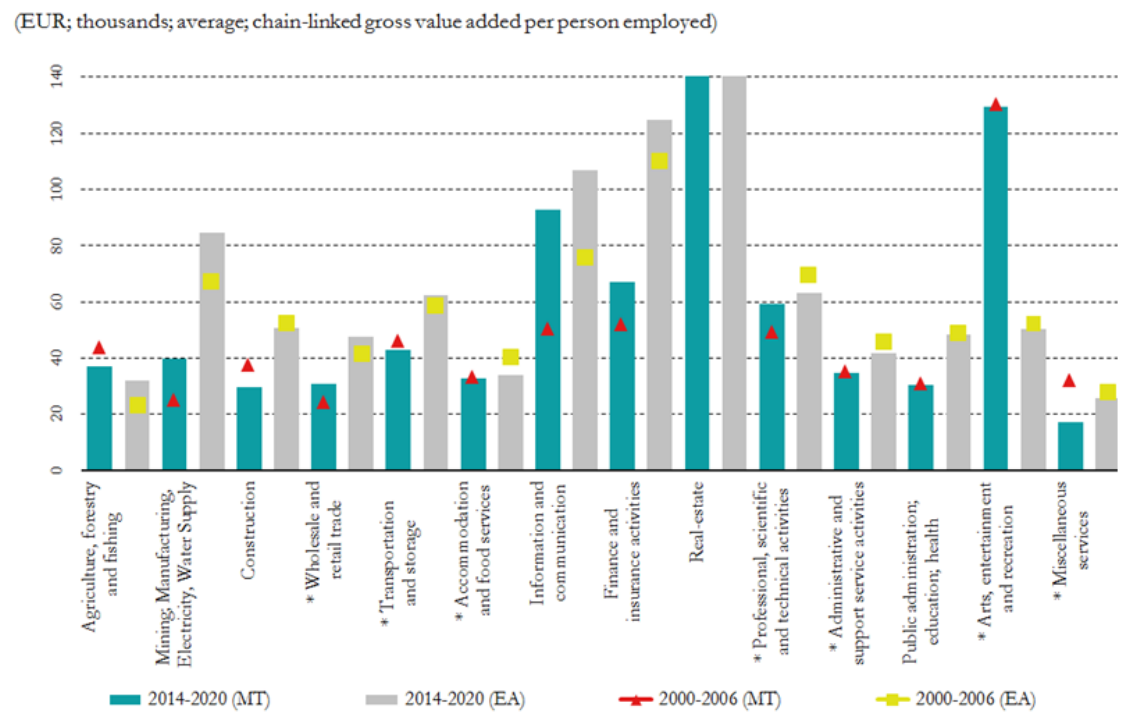

*Euro area data is an average of 2014-2019, as 2020 data were unavailable at the time of publication

Chart 1: Sectoral productivity (The significanly above-average productivity levels of real-estate activites reflect the inclusion of imputed rents of owner-occupied dwellings.)

Source: Eurostat; authors' calculations 
Chart 1 also provides a comparison of sectoral productivity levels in 2014-2020 with the average for 2000-2006. ${ }^{7}$ As in 2014-2020, the highest productivity levels in 2000-2006 were mainly recorded in services sectors. The information \& communication sector in Malta saw substantial growth in its real productivity level between the two subperiods, largely reflecting developments in the telecommunications subsector. This was a result of real output growth outpacing job creation. Financial \& insurance activities also experienced substantial growth in productivity during the intervening period. This surge was largely due to robust growth in real output, particularly in the years leading up to the Great Recession, albeit to a lesser extent than in the information \& communication sector. Productivity levels in this sector stabilised in more recent years, though at a higher level than the average for 2000-2006.

The manufacturing sector also registered an increase in productivity levels, largely due a decline in employment levels. On the other hand, the construction sector and smaller industries such as miscellaneous services and agriculture \& fishing registered a drop in productivity levels. Meanwhile, the transportation \& storage sector, the sectors comprising public administration, health \& education, the administrative \& support services sector, accommodation \& food activities, and the arts, entertainment \& recreation sector showed little to no change in their productivity levels between the two periods.

Real output per person employed in the 2014-2020 subperiod was higher in the euro area for most economic sectors when compared with Malta, apart from the arts, entertainment \& recreation sector and agriculture \& fishing. Nevertheless, economy-wide productivity in Malta converged towards euro area productivity levels during 2014-2020, relative to the values registered in 2000-2006 (Montebello \& Darmanin, forthcoming). This convergence process towards aggregate productivity levels recorded in the euro area occurred as labour productivity grew at a faster pace in Malta. From a sectoral viewpoint, this was largely driven by the services sector - particularly the professional, scientific \& technical activities sector and the information \& communication sector. Although the information \& communication sector registered substantial growth in both Malta and the euro area, the growth rate in Malta outpaced that of the euro area. On the other hand, the professional, scientific \& technical activities sector registered productivity improvements in Malta but efficiency loses were recorded at the euro area level.

Apart from generating the highest level of labour productivity, services sectors in Malta also recorded the largest levels of real compensation per employee in the 2014-2020 subperiod. This is shown in Chart 2. The arts, entertainment \& recreation sector recorded the largest real compensation per employee, averaging $€ 43,240$. This was followed by the financial \& insurance activities and the information \& communication sectors, with the latter recording significant growth since 2000-2006.

Similar to Malta, the highest real compensation per employee in the euro area were generated in services sectors. The two largest compensation levels were recorded in the sectors with the highest levels of labour productivity in the bloc, namely the finance \& insurance activities sector and the information \& communication sector, at $€ 70,920$ and $€ 62,860$ respectively.

The sector which registered the lowest average level of compensation per employee in Malta during the 2014-2020 subperiod was the sector comprising of miscellaneous services. This sector mainly comprises low-skilled occupations. This was followed by the wholesale \& retail trade and construction sectors. The trade sector, which is the second largest in terms of employment, recorded a below-average real compensation per employee in recent years, in line with its low productivity levels. On the other hand, the largest sector in Malta in terms of employment, namely the one comprising public administration, health \& education recorded slightly above-average real compensation per employee, despite its relatively low productivity levels.

\footnotetext{
${ }^{7}$ For a detailed analysis of developments in sectoral productivity levels in 2020 see Montebello and Darmanin (2020). 


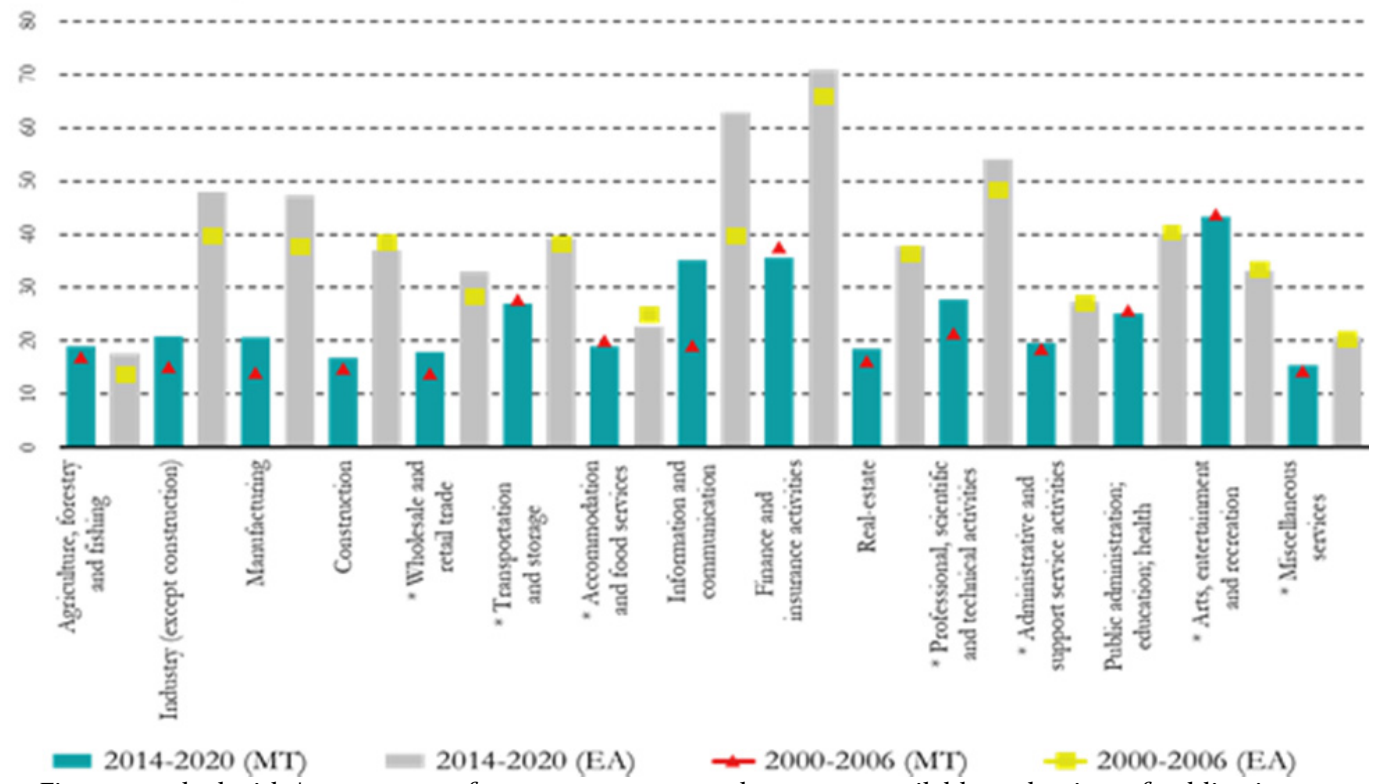

Figures marked with * are averages for 2014-2019, as 2020 data was unavailable at the time of publication

Chart 2: Real compensation per employee

Source: Eurostat; authors' calculations

As in 2014-2020, the highest levels of compensation per employee in the 2000-2006 subperiod were mainly recorded in services sectors, such as the arts, entertainment \& recreation sector and financial \& insurance activities. However, the information \& communication sector recorded below average real compensation per employee levels during the first subperiod, in contrast to the levels recorded in 20142020. This large increase mirrors the rise in chain-linked productivity in this sector during the intervening period. The manufacturing sector also recorded a sharp increase in compensation per employee when comparing the two subperiods, as productivity levels improved. Nevertheless, compensation per employee in this sector remained below the aggregate economy average in 2014-2020.

In the remaining sectors - bar the accommodation and food services and the professional, scientific \& technical sectors - average real compensation per employee remained largely unchanged between 2000-2006 and 2014-2020. This is likely because these of sectors recorded relatively stable or declining productivity levels, and compensation normally tends to respond to productivity increases. In contrast, nominal data shows that compensation per employee increased in each sector since 2000-2006. On an aggregate level, nominal compensation per employee increased more than the corresponding value in real terms.

Despite an overall improvement in the level of real compensation per employee in several sectors in Malta in the two decades since 2000, the differences in compensation levels between Malta and the euro area were still quite substantial in the last subperiod. The only two sectors in which average real compensation in Malta was higher than that in the euro area in 2014-2020 were the agriculture \& fishing sector and the arts, entertainment \& recreation sector. Nonetheless, some convergence does seem to have occurred in certain sectors. Growth rates in compensation levels in Malta were larger than those in the euro area, especially in the information \& communication, manufacturing, construction, and the professional, scientific \& technical activities sectors. Indeed,

${ }^{8}$ A comparison of chain-linked and nominal compensation per employee by sector is provided in Appendix II. 
economy-wide average real compensation per employee in Malta stood at $62.1 \%$ of euro area compensation levels during 2014-2020, rising from 57.7\% in 2000-2006.

Chart 3 shows developments in real ULC in Malta and the euro area, measured as the ratio of real compensation per employee to chain-linked productivity per employed person. In the 2014-2020 subperiod, the highest real ULC in the Maltese economy were recorded in the sectors relating to miscellaneous services and public administration, education \& health activities. These were followed by the transportation \& storage sector. On the other hand, the lowest ULC were registered in real estate activities, the information \& communication sector, and the arts, entertainment, \& recreation sector. This was largely a result of these sectors having the highest productivity levels during these years.

On an aggregate level, average ULC in Malta during the 2014-2020 subperiod were below those registered in the euro area. Indeed, at a sectoral level, only the ULC of those sectors which registered the highest ULCs in Malta - miscellaneous services and the transportation \& storage sector surpassed the corresponding real ULC values in the euro area.

When assessed over a longer horizon, ULC in real terms remained largely unchanged in most sectors. However, miscellaneous services and the construction sector recorded large increases in their ULC between 2000-2006 and 2014-2020, due to increasing real compensation per employee and declining productivity levels. In contrast, finance \& insurance activities registered a decline in ULC over the same time-period, largely due to productivity improvements in the sector.

(EUR; avemag; matio of nal compensation per employee to output per person employed)

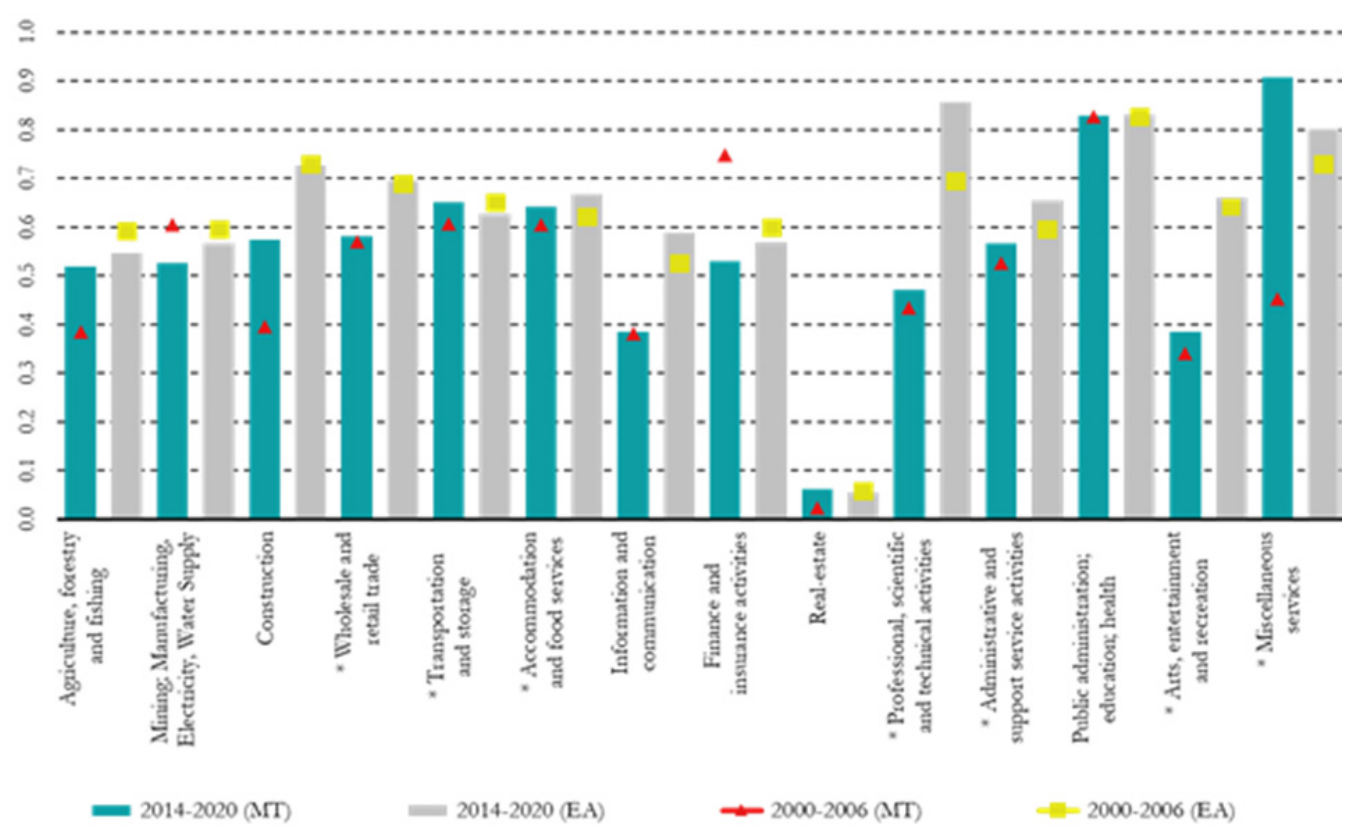

* Euro area data is an average of 2014-2019, as 2020 data were unavailable at the time of publication

Chart 3: Sectorial real unit labour costs

Source: Eurostat; authors' calculations

\section{Developments in Sectoral Deflators}

This section describes developments in output prices between 2000 and 2020. Table 6 depicts the 
evolution of sectoral deflators in the past two decades, showing average annual growth in each of the three subperiods in Malta and the euro area.

Most sectors recorded increases in their output deflators over the years. The largest increases were observed in finance \& insurance activities, the arts, entertainment \& recreation sector, and the sector comprising public administration, education \& health. Such developments could reflect a number of factors, including the development of new products/services and pure price increases due to changes in cost and wage pressures, such as labour shortages and union power.

On the other hand, the deflator for information and communication shows a significant decline since 2007. This could reflect the technological progress that affects this sector globally, leading to constant improvement in quality at a reduced production cost.

Developments in deflators were more mixed outside the services sector. The deflator for the manufacturing sector declined during the $2007-2013$ period. This was a period of turbulence for this industry, which underwent significant structural and regulatory changes, in part owing to EU accession in 2004. More recently, the deflators in this sector have increased, though not at the same rates observed in some services sectors. This could reflect a structural shift in this sector toward higher value-added industries, such as pharmaceuticals (Borg Caruana, 2018).

Similarly, the wholesale and retail trade sector recorded only moderate growth in output prices, particularly in more recent years. These developments could reflect increased competitive pressures within the sector, such as e-commerce and the presence of a number of international firms in Malta.

When compared with the euro area, growth in the deflators in Malta was stronger in several sectors, particularly in services sectors from 2007 onwards. In part, this could reflect the divergence in economic developments between Malta and the euro area during recent years. While Malta experienced a period of strong economic growth, driven by developments in the services sector, activity in the euro area remained sluggish following the impact of the Global Financial Crisis and the sovereign debt crisis.

Table 6: Sectoral deflators in Malta and the euro area

$\%$ change; averages

\begin{tabular}{|c|c|c|c|c|c|c|}
\hline & 2001-2006 & $\begin{array}{c}\text { MALTA } \\
2007-2013 \\
\end{array}$ & 2014-2020 & $\begin{array}{r}\text { EI } \\
2001-2006 \\
\end{array}$ & $\begin{array}{l}\text { URO ARE } \\
2007-2013\end{array}$ & $\begin{array}{l}\mathbf{E A} \\
32014-2020 \\
\end{array}$ \\
\hline Agriculture, forestry and fishing & -3.5 & 3.8 & 0.4 & -0.3 & 1.2 & 1.0 \\
\hline Industry (excl. construction) & 1.1 & 0.2 & 0.6 & 0.9 & 1.2 & 1.0 \\
\hline of which: Manufacturing & 0.4 & -0.6 & 1.0 & 0.2 & 0.9 & 1.1 \\
\hline Construction & 3.0 & 2.3 & 1.7 & 4.1 & 2.3 & 2.6 \\
\hline Wholesale and retail trade; vehicle repair & 1.5 & 0.9 & 0.5 & 1.2 & 1.2 & $0.6^{*}$ \\
\hline Transportation and storage & 3.0 & 3.3 & 1.0 & 1.6 & 1.6 & $1.7^{*}$ \\
\hline Accommodation and food services & 3.7 & 2.3 & 0.4 & 3.1 & 1.4 & $2.2^{*}$ \\
\hline Information and communication & 3.1 & -2.6 & -0.9 & -0.6 & -1.8 & 0.0 \\
\hline Finance and insurance activities & 5.6 & 3.5 & 2.3 & 4.1 & 0.8 & 0.7 \\
\hline Real estate activities & 1.4 & 2.0 & 3.2 & 3.1 & 1.4 & 1.4 \\
\hline Professional, scientific and technical activities & 2.6 & 2.5 & 2.4 & 2.3 & 1.5 & $1.1^{*}$ \\
\hline Administrative and support service activities & 2.6 & 2.2 & 1.7 & 2.5 & 2.0 & $1.6^{*}$ \\
\hline $\begin{array}{l}\text { Public administration and defence; education, health and } \\
\text { social work activities }\end{array}$ & 3.9 & 3.7 & 3.3 & 3.1 & 1.9 & 1.9 \\
\hline Arts, entertainment and recreation & 1.9 & 9.1 & 6.3 & 2.8 & 2.0 & $1.1 *$ \\
\hline Miscellaneous services & 1.9 & 1.8 & 1.0 & 2.8 & 1.9 & $0.8^{*}$ \\
\hline
\end{tabular}

Notes: Figures marked with * are averages for 2014-2019, as 2020 data was unavailable at the time of publication

Source: Eurostat; authors' calculations

Growth in the overall GDP deflator averaged between $2.0 \%$ and $2.5 \%$ during most of the period under review. As shown in Table 7, the largest contributor to growth in the overall deflator was consistently the sector comprising public administration, education \& health - reflecting its large weight in total output and above-average growth in its deflator. From 2007 onward, the deflator for the arts, entertainment \& 
recreation industry also had a substantial impact on growth in the GDP deflator. Other services sectors excluding information \& communication - and the construction sector consistently contributed positively to growth in the GDP deflator, though to a lesser extent. On the other hand, the impact of the primary and industrial sectors (excluding construction) on growth in the economy-wide deflator was small on average.

Table 7: Contributions to growth in GDP deflator

\begin{tabular}{lccc} 
percentage points; averages & & & \\
\hline & $2001-2006$ & $2007-2013$ & $2014-2020$ \\
\hline Agriculture, forestry and fishing & -0.1 & 0.0 & 0.0 \\
Industry (excl. construction & 0.2 & 0.0 & 0.0 \\
of which: Manufacturing & 0.1 & -0.1 & 0.1 \\
Construction & 0.2 & 0.1 & 0.1 \\
Wholesale and retail trade; vehicle repair & 0.2 & 0.1 & 0.0 \\
Transportation and storage & 0.2 & 0.2 & 0.1 \\
Accommodation and food services & 0.2 & 0.1 & 0.0 \\
Information and communication & 0.1 & -0.1 & -0.1 \\
Finance and insurance activities & 0.2 & 0.3 & 0.2 \\
Real estate activities & 0.1 & 0.1 & 0.2 \\
Professional, scientific and technical activities & 0.1 & 0.1 & 0.2 \\
Administrative and support service activities & 0.1 & 0.1 & 0.1 \\
Public administration and defence; education, health and social work activities & 0.6 & 0.6 & 0.5 \\
Arts, entertainment and recreation & 0.0 & 0.5 & 0.6 \\
Miscellaneous services & 0.1 & 0.1 & 0.0 \\
Net Taxes & 0.4 & 0.3 & 0.5 \\
GDP deflator (\% growth) & 2.5 & $\mathbf{2 . 3}$ & $\mathbf{2 . 4}$ \\
\hline
\end{tabular}

Source: Eurostat; authors' calculations

\section{Conclusion}

Using the newly available chain-linked sectoral national accounts data, this analysis shows that there was a strong shift towards services sectors in the Maltese economy during the two decades since 20oo. This confirms the findings of earlier studies, which were based on nominal data owing to the unavailability of chain-linked output data at the time. This shift towards the services industry observed through both the rising share in output and in employment of these sectors - was more pronounced when compared with the euro area. In turn, the decline in the employment share of the Maltese manufacturing sector was significantly above the corresponding decline in the euro area.

Additionally, services sectors in general generated the largest average productivity levels in recent years, as well as the lowest ULC. However, developments across sectors vary. Whereas the sector primarily consisting of gambling \& betting activities registered the highest level of productivity in Malta, financial \& insurance activities and the information \& communication sector were the most productive sectors at euro area level. Nonetheless, real output per person employed in most sectors was higher in the euro area relative to productivity levels in Malta. Similarly, average compensation per employee levels in Malta were highest in services sectors, particularly those with higher productivity levels. However, compensation levels in Malta generally remain below euro area levels, though convergence is taking place.

This study also analyses developments in sectoral output deflators since 2000. Growth in the overall deflator in Malta has primarily been driven by developments in services output prices. Indeed, when compared with the euro area, growth in deflators in Malta was stronger in several sectors, particularly from 2007 onwards. This could reflect the strong economic growth observed in Malta during the intervening period, compared with the sluggish recovery in the euro area following the Great Recession and euro crisis, as well as some progress with price convergence.

Since this study is based on national accounts data, the provided results may be sensitive to 
frequent data revisions. There are several ways in which this study on the structural change in the Maltese economy may be expanded. A more detailed analysis could be conducted should more disaggregated NACE data, perhaps at two-digit level, become publicly available. The newly available sectoral deflators also open the door to a depth of potential research into sectoral productivity and competitiveness in Malta. Examples include an analysis of the sectoral drivers of real labour productivity growth and ULC in Malta, as well as a study on Malta's price competitiveness in terms of output prices.

\section{Acknownledgment}

The authors would like to thank the following persons from the Central Bank of Malta for the help and feedback provided during this study: Mr. Alexander Demarco, Dr. Aaron G. Grech, Dr. Brian Micallef, Ms. Rita Schembri, Mr. Ian Borg. Any errors are the authors' responsibility.

\section{References}

Attard, S. (2020). Evolution of tourism, challenges, and its sustainability in an island state: Case study of Malta. International Journal of Islands Research, 1(1), 6.

Borg Caruana, J. (2018). Developments in the manufacturing sector.

Borg Caruana, J. (2019). Developments in the wholesale \& retail sector.

Cassar, I. P. (2017). Assessing structural change in the Maltese economy via the application of a hypothetical extraction analysis.

Central Bank of Malta. (2003). Thirty-sixth annual report and statement of accounts.

Eurostat. (2021). National accounts aggregates and employment data by industry (nama_10_a64 \& nama_10_a64_e).

Gatt, W., \& Grech, O. (2016). An assessment of the Maltese housing market.

Grech, A.G., \& Zerafa, S. (2015). Evaluating the diversification of the Maltese economy.

Grech, A. G. (2015a). Structural changes in the Maltese economy. Mediterranean Journal of Social Sciences, 6(5), 423.

Grech, A. G. (2015b). The diversification of the Maltese economy.

Grech, A. G. (2017). Did Malta's accession to the EU raise its potential growth?: A focus on the foreign workforce. Journal of Economic Integration, 873-89o.

Micallef, B. (2016). Determinants of labour productivity in Malta: Evidence from a firm-level survey. Economics \& Sociology, 9(4), 27.

Micallef, B. (2017). A sectoral supply-side model to assess the impact of labour market reforms in Malta.

Micallef, B. (2019). Measuring the effects of structural reforms in Malta.

Montebello, R., \& Darmanin, J., (2021) Sectoral Contributions to aggregate labour productivity and ULC growth, Central Bank of Malta, 2020 Annual Report, pp. 81-86.

Montebello, R., \& Darmanin, J., (forthcoming) Labour productivity growth in Malta: A sectoral decomposition analysis

National Statistics Office. (2020). Benchmark revision 2020. Retrieved from https://nso.gov.mt/en/nso/Sources_and_Methods/Documents/National_Accounts/National\%2oAccounts\% 20-\%2oBenchmark\%2oRevision\%202020.pdf

Rapa, N. (2017). The macroeconomic effects of efficiency gains in electricity production in Malta. 


\section{Appendix I:}

Table 8: Comparison of nominal and chain-linked contributions to output growth

percentage points; averages

\begin{tabular}{|c|c|c|c|c|c|c|}
\hline & \multicolumn{3}{|c|}{ NOMINAL } & \multicolumn{3}{|c|}{ DIFFERENCE (FROM CHAIN-LINKED) } \\
\hline & $2000-2006$ & $2007-2013$ & 2014-2020 & $2000-2006$ & $2007-2013$ & 2014-2020 \\
\hline Agriculture, forestry and fishing & 0.1 & 0.0 & 0.0 & 0.1 & -0.1 & 0.0 \\
\hline Industry (excl. construction) & -0.5 & 0.3 & 0.5 & -0.2 & 0.0 & -0.1 \\
\hline of which: Manufacturing & -0.6 & 0.3 & 0.3 & -0.1 & 0.1 & -0.1 \\
\hline Construction & 0.4 & 0.0 & 0.3 & -0.2 & -0.1 & -0.1 \\
\hline Wholesale and retail trade; vehicle repair & 0.3 & 0.6 & 0.4 & -0.2 & -0.1 & 0.0 \\
\hline Transportation and storage & 0.0 & 0.3 & 0.1 & -0.2 & -0.2 & -0.1 \\
\hline Accommodation and food services & 0.0 & 0.3 & -0.1 & -0.2 & -0.1 & 0.0 \\
\hline Information and communication & 0.4 & 0.3 & 1.1 & -0.2 & 0.2 & 0.1 \\
\hline Finance and insurance activities & 0.8 & 0.8 & 0.5 & -0.3 & -0.3 & -0.2 \\
\hline Real estate activities & 0.3 & 0.3 & 0.5 & -0.1 & -0.1 & -0.2 \\
\hline Professional, scientific and technical activities & 0.4 & 0.5 & 1.2 & -0.1 & -0.1 & -0.2 \\
\hline Administrative and support service activities & 0.2 & 0.4 & 0.9 & -0.1 & -0.1 & -0.1 \\
\hline $\begin{array}{l}\text { Public administration and defence; education, } \\
\text { health and social work activities }\end{array}$ & 1.1 & 1.1 & 1.2 & -0.7 & -0.7 & -0.6 \\
\hline Arts, entertainment and recreation & 0.4 & 1.2 & 0.8 & 0.0 & -0.6 & -0.7 \\
\hline Miscellaneous services & 0.1 & 0.1 & 0.1 & 0.0 & 0.0 & 0.0 \\
\hline GVA (\% growth) & 4.1 & 6.0 & 7.6 & -2.4 & -2.4 & -2.2 \\
\hline
\end{tabular}

Notes: Output is defined as chain-linked GVA. Chain-linked contributions are shown in Table 2.

Source: Eurostat; authors' calculations

\section{Appendix II:}

Table 9: Compensation per Employee in Malta

EUR; thousands; subperiod averages

\begin{tabular}{lccc|ccc}
\hline & & \multicolumn{3}{c}{ Nominal } \\
& $2000-2006$ & $2014-2020$ & Change & $2000-2006$ & $2014-2020$ & Change \\
\hline Total - all NACE activities & 20.8 & 24.2 & $16.1 \%$ & 15.9 & 25.0 & $57.8 \%$ \\
Agriculture, forestry and fishing & 16.9 & 19.0 & $12.1 \%$ & 15.8 & 18.8 & $18.8 \%$ \\
Industry (excl. construction) & 15.2 & 20.8 & $37.0 \%$ & 14.5 & 21.2 & $46.1 \%$ \\
of which: Manufacturing & 14.1 & 20.6 & $46.2 \%$ & 14.5 & 21.1 & $46.2 \%$ \\
Construction & 14.8 & 16.8 & $13.7 \%$ & 11.4 & 17.4 & $53.1 \%$ \\
Wholesale and retail trade & 13.9 & 17.9 & $28.9 \%$ & 12.5 & 18.2 & $45.4 \%$ \\
Transportation and storage & 27.8 & 27.0 & $-2.9 \%$ & 20.4 & 28.0 & $37.1 \%$ \\
Accommodation and food services & 20.0 & 18.9 & $-5.6 \%$ & 15.2 & 18.7 & $23.3 \%$ \\
Information and communication & 19.2 & 35.2 & $83.2 \%$ & 20.8 & 33.5 & $60.7 \%$ \\
Finance and insurance activities & 37.6 & 35.6 & $-5.4 \%$ & 24.3 & 37.5 & $53.9 \%$ \\
Real-estate & 16.3 & 18.5 & $13.6 \%$ & 13.1 & 19.9 & $52.6 \%$ \\
Professional, scientific and technical activities & 21.5 & 27.7 & $29.3 \%$ & 16.1 & 29.2 & $81.4 \%$ \\
Administrative and support service activities & 18.5 & 19.6 & $6.4 \%$ & 14.4 & 20.3 & $40.7 \%$ \\
Public administration; education; health & 25.8 & 25.2 & $-2.5 \%$ & 17.3 & 26.8 & $54.6 \%$ \\
Arts, entertainment and recreation & 43.7 & 43.2 & $-1.1 \%$ & 18.8 & 46.0 & $145.0 \%$ \\
Miscellaneous services & 14.3 & 15.5 & $8.1 \%$ & 11.7 & 15.7 & $34.2 \%$ \\
\hline
\end{tabular}

Source: Eurostat; authors' calculations 